\title{
SCREENING FOR EXTRACELLULAR ENZYMES AND PRODUCTION OF CELLULASE BY AN ENDOPHYTIC ASPERGILLUS SP, USING CAULIFLOWER STALK AS SUBSTRATE
}

\author{
Prabavathy. D \& Valli Nachiyar C \\ Department of Biotechnology, Sathyabama University, Jeppiaar Nagar, Chennai - 119, Tamilnadu, India. \\ Email: prabagrp@yahoo.co.in
}

\begin{abstract}
Agricultural and industrial wastes are among the causes of environmental pollution. Their conversion to useful products may ameliorate the problems they cause. The present study was carried out to maximize economic benefits by microbial activity for waste management. Endophytic Aspergillus $s p$ of Adathoda beddomei was screened for production of various hydrolytic enzymes. The production of cellulase using cauliflower stalk as substrate was reported. The saccharification of cauliflower stalk by endophytic Aspergillus was studied by CMC assay and FPU assay with potato pieces as control substrate. The effect of time on the cellulase activity indicated that the activity was at peak till 6 days, whereas it decreased from the $7^{\text {th }}$ day.
\end{abstract}

Key words: cellulase; waste management; CMC assay; Aspergillus; endophyte

\section{INTRODUCTION}

Of recent ,the potential use of microorganisms as biotechnological sources of industrially relevant enzymes have stimulated interest in exploration of extracellular enzymatic activity in several microorganisms. Endophytic fungi are those fungi which colonise plants internally without apparent adverse effect (1). Endophytic fungi are relatively unexplored producers of metabolites useful to pharmaceutical and agricultural industries. A single endophyte produce several bioactive metabolites. As a result, the role of endophytes in production of various natural products with greater bioactivity have received increased attention (2,3). Extracellular enzyme synthesis in endophytic fungi for penetrating the host plant cell wall, as well as biocontrol has been demonstrated previously $(4,5)$. The confirmation of the potential for enzyme secretion by a species and the analysis of the conditions of production could lead to improvement of the environmental condition favouring the maximal exploration of this capacity.

Higher cost of refined refined substrates are the limiting factor in the economics of enzyme production. hence utilisation of relatively inexpensive, alternate substrates such as different agroindustrial by products,waste paper, saw dust,municipal solid waste and liquid waste as productive media for fungal natural products and enzymes were described(6).
In our present investigation,we screened the endophytic Aspergillus $s p$ isolated from Adathoda beddomei for the ability to produce amylase,cellulase,protease and lipase. As part of the study we report the production of cellulase using cauliflower stalk waste as substrate. The effect of time on biomass production and cellulase activity was studied using potato pieces as control substrate.

\section{MATERIALS AND METHODS}

\section{A. Isolation of Endophytes}

Healthy leaves of Adhathoda beddomei, were collected from Siddha Institute, Chennai. Samples were cleaned under running tap water and then air dried. Surface sterilization was carried out by sequential washings in $70 \%$ ethanol for $1 \mathrm{~min}, 5 \%$ sodium hypochlorite solution for $5 \mathrm{~min}$ and sterile distilled water for $1 \mathrm{~min}$ twice. The surface sterilized leaves were cut in to small pieces using a sterile blade and transferred to sterile Potato dextrose agar (PDA) plate supplemented with chloramphenicol $(50 \mu \mathrm{g} / \mathrm{ml})$. The plates were incubated at $27^{\circ} \mathrm{C}$ for $7-14$ days. The endophytic fungi grown on plates were transferred to sterile PDA slants to maintain culture purity. The fungi were identified by colony morphology and LPCB mount $(7,8)$.

\section{B. Screening endophytic fungi for enzyme production}

The fungal endophytes were cultivated on potato dextrose broth by placing agar block of actively growing 
pure culture in $250 \mathrm{ml}$ Erlenmeyer flask containing $100 \mathrm{ml}$ of the medium. The flasks were incubated at $27^{\circ} \mathrm{C}$ for 7 days with periodical shaking at $150 \mathrm{rpm}$. After the incubation period, the cultures were taken out and filtered through sterile mesh cloth to remove mycelia mats. The crude filtrate was used as the sample for qualitative enzyme analysis as described by Kumaresan and Suryanarayanan (9).

\section{Cellulase}

Nutrient agar was prepared supplemented with $0.5 \%$ of Na-CMC. Wells were punched on the agar plates. $1 \%$ congo red for few minutes and destained with $1 \mathrm{M} \mathrm{Nacl}$ several times. Clear zone around the wells indicated production of cellulase

\section{Amylase}

GYP medium ( $1 \mathrm{~g}$ glucose $+0.1 \mathrm{~g}$ yeast extract $+0.5 \mathrm{~g}$ peptone, $16 \mathrm{~g}$ agar in $1000 \mathrm{ml}$ of distilled water) was supplemented with $2 \%$ starch. $50 \%$ of filtrate was added to the wells on starch agar and incubated for 16-24 hrs. After the incubation period, plates were flooded with iodine stain. Clear zone around the wells indicates production of amylase.

\section{Lipase}

Nutrient agar supplemented with $1 \%$ of Tween. $50 \%$ of filtrate added to the wells and incubated for 16-24 hrs.A clearing or precipitation around the wells indicates lipolytic activity .

\section{Protease}

GYP medium was supplemented with $0.4 \%$ gelatin. $50 \%$ of filtrate added to the wells on gelatin agar and incubated for 16-24 hrs. The plates were flooded with saturated ammonium sulphate. A zone of precipitin around the wells indicate production of protease.

\section{Quantitative enzyme assay}

The filtrate has been used for the standard quantitative assays of the hydrolytic enzymes.

\section{Amylase}

To $1 \mathrm{ml}$ of the filtrate , $1 \mathrm{ml}$ of starch (1\% soluble starch on $0.02 \mathrm{M}$ disodium hydrogen phosphate and $0.006 \mathrm{M}$ sodium chloride at $\mathrm{pH} 6.9$ ) was added and incubated at $45^{\circ} \mathrm{C}$ for 1 hour. To the above mixture, 3 $\mathrm{ml}$ of dinitro salicylic acid (DNSA) was added and kept in boiling for 5 minutes and cooled. The reddish brown colour was observed which was measured spectrometrically at $540 \mathrm{~nm}$. Amount of sugars produced were read off from a standard curve obtained by recording the absorbance of concentration of maltose standard solution.

\section{Protease}

To $3 \mathrm{ml}$ of culture filtrate, $3 \mathrm{ml}$ of phosphate buffer and $3 \mathrm{ml}$ of $1 \%$ casein was added and incubated at $35^{\circ} \mathrm{C}$ for 1 hour. To this $5 \mathrm{ml}$ of $20 \%$ TCA was added and kept undisturbed for 1 hour . the solution was filtered with whatmann no 540 . From the above filtrate, $1 \mathrm{ml}$ was taken to which $2 \mathrm{ml}$ of $20 \%$ sodium carbonate solution was added along with $1 \mathrm{ml}$ of Folin Ciocalteu reagent and mixed thoroughly and incubated for 30 minutes. $6 \mathrm{ml}$ of distilled water was added and the absorbance was measured spectrometrically at $660 \mathrm{~nm}$. From the standard curve,the amount of enzyme liberated was calculated.

\section{Cellulase}

$1 \mathrm{ml}$ of carboxmethyl cellulose (CMC) was added to $1 \mathrm{ml}$ of the filtrate and incubated for 50 minutes at room temperature . $2 \mathrm{ml}$ of Dinitrosalicylic acid (DNSA) was added and boiled at $90^{\circ} \mathrm{C}$ for 10 minutes and cooled. To this reaction mixture $1 \mathrm{ml}$ of sodium potassium tartarate solution was added and the absorbance was measured spectrometrically at $540 \mathrm{~nm}$.

\section{Inoculation and culture conditions for cellulase production}

The strain maintained on PDA slants at $40 \mathrm{C}$ for 6 days were prepared as conidial suspensions by washing slant cultures with $5 \mathrm{ml}$ sterilized water. Spore suspension was counted at $10^{6}$ spores $/ \mathrm{ml}$ by Haemacytometer. All trials were carried out in $250 \mathrm{ml}$ Erlenmeyer flasks containing $10 \mathrm{~g}$ of cauliflower stalk (cut into small pieces) and potato pieces (control substrate) mixed with $5 \mathrm{ml}$ of PDB.

\section{Cellulase assays}

Filter paper activity for total cellulase activity was determined by standard method. Aliquots of appropriately diluted culture filtrate as enzyme source were added to Whatmann no 1 filter paper strip immersed in one $\mathrm{ml}$ of $0.05 \mathrm{M}$ sodium citrate buffer of $\mathrm{pH}$. After incubation at $50 \pm 2^{\circ} \mathrm{C}$ 
for $1 \mathrm{hr}$, the reducing sugar released was estimated by DNS method. One unit of FPU activity was defined as the amount of enzyme releasing $1 \mu$ mole of reducing sugar from filter paper per minute.

Endoglucanase activity was measured using a reaction mixture containing $1 \mathrm{ml}$ of $1 \% \mathrm{CMC}$ in $0.5 \mathrm{M}$ citrate acetate buffer ( $\mathrm{pH} \mathrm{5.0)}$ and aliquots of suitably diluted filtrate. The reaction mixture was incubated at $50 \pm 2^{\circ} \mathrm{C}$ for $1 \mathrm{hr}$, and the reducing sugar produced was determined by DNS method. One unit of endoglucanase was defined as the amount of enzyme that liberated $1 \mu \mathrm{mol}$ of glucose per $\mathrm{ml}$ per minute of reaction (10).

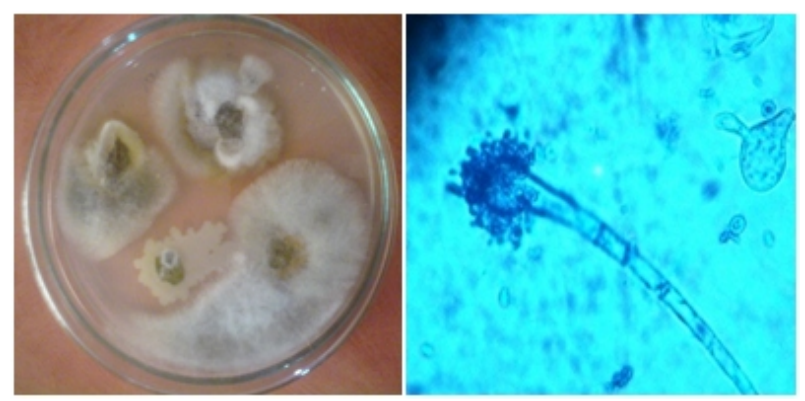

Fig. 1. Growth of endophytic fungi on PDA and LPCB mount showing the morphology of isolated fungi

Discovery of endophytic fungi in plant tissues opened up new possibilities in the search for metabolically active compounds. According to Dreyfuss and Chapela about 4000 secondary metabolites of fungal origin have been described as biologically active(11) .

Substrate utilization studies on fungal endophytes of various plants have conclusively demonstrated that most endophytes are able to utilize most substrates present in the cell walls of the hosts for their capacity to produce some extracellular enzymes. Foliar endophytes are also involved in litter decomposition $(12,13)$.

In this study, endophytic fungi belonging to Adhathoda beddomei was isolated. The fungus was identified as Aspergillus sp by LPCB mount. As shown in Figure 1. The fungi isolated was screened for cellulase, amylase, protease and lipase production. The fungi was positive for all the enzymes screened as shown in Figure 2. Cellulases, amylases, proteases belong to the class of hydrolases which breakdown lignocellulosic material of the plants. Amylase production by endophytic fungi has been reported by Frohlich et al (14). Since the endophyte lives within the senescent tissues, they are the initial colonizers of the dead tissue and utilize the readily available starch by production of amylase. Cellulases are consortia of hydrolytic enzymes converting cellulose to glucose units [3].The production of protease, cellulase and lipase indicates the capability of the fungi to degrade the cuticular wax of the leaf surface and ability to penetrate the cell wall. Moreover it indicates the pattern of plant-fungal relationship from mutualistic to latent pathogen (4).

The quantitative analysis indicated the level of enzyme production. $40 \mu \mathrm{g} / \mathrm{ml}$ of anylase, $32 \mu \mathrm{g} / \mathrm{ml}$ of protease and $60 \mu \mathrm{g} / \mathrm{ml}$ of cellulase was produced respectively by the endophytic Aspergillus $\mathrm{sp}$.

The production of hydrolytic enzymes on agro, industrial, municipal wastes have been demonstrated by various workers(15). Large quantities of cellulosic wastes, generated from agricultural residues, forests and agro-industrial practices generally accumulate in the environment and cause pollution problem (16). Biodegradation of cellulosic wastes is accomplished by cellulolytic enzymes and cellulase is a synergistic enzyme that is used to break up cellulose into glucose or other oligosaccharide compounds. Active efforts are being made to convert waste cellulose resources into either glucose or alcohol and use this either as fuel or
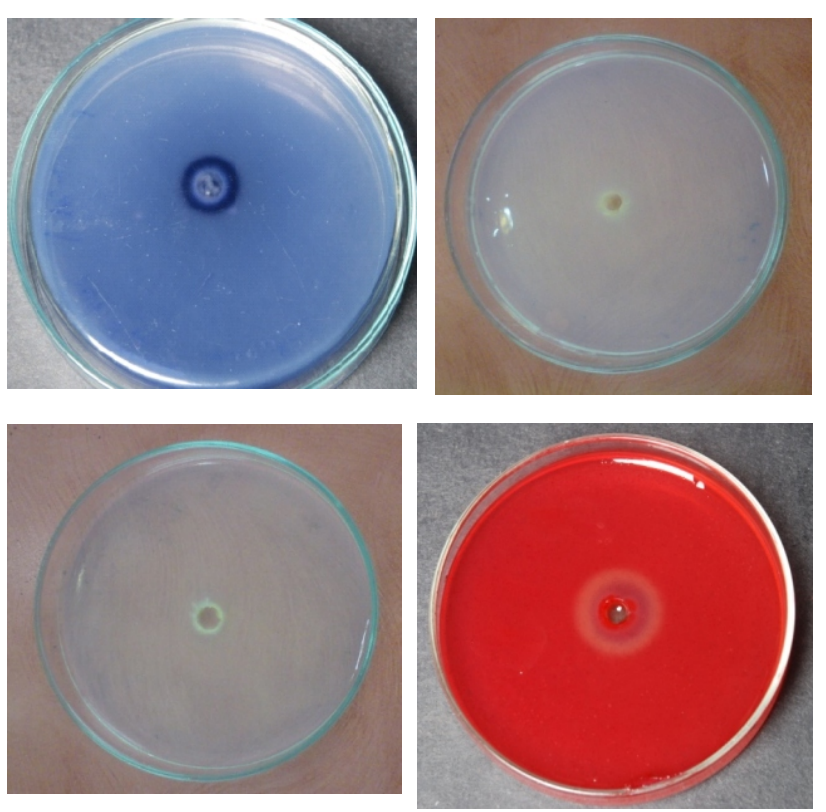

Fig. 2. Extracellular enzyme production by endophytic Aspergillus sp 
as a valuable starting material for chemical synthesis. Large scale production of cellulase for commercial purposes requires the identification of high yielding fungal sources and optimization of process conditions (17). Different agroindustrial by products like sugarcane bagasse, corn bran,wheat bran,fenugreek straw as productive media for fungl natural products were described Mohamed Ashour et al (18). Banana fruit stalks have been confirmed to be good solid substrates for production of cellulase by Neurospora sitophila at optimized culture conditions(19).

In accordance with the above studies, the production of cellulase by endophytic Aspergillus sp on cauliflower stalk waste was accomplished by solid state fermentation.

Growth of the fungi on the solid state culture as well as cellulase production, by the isolated Aspergillus sp. were followed simultaneously for 7 days using Cauliflower stalk pieces (CFSP) and potato pieces (PP) as substrates. Results clearly indicated that PP supported growth comparatively more than CFSP and growth reached maximum on day 6 producing nearly $4.2 \mathrm{gm} / 10 \mathrm{gm}$ of substrate used (Figure 3). This variation in the biomass production when different substrates were used is due to the fact that CFSP is a tough substrate to be acted upon by the fungal species compared to PP. Even Moumita Karmaker and Rina Rani Roy reported the differential rate of saccharification of sugar cane bagasse, water hyacinth and orange peel and attributed this difference to the nature and complexity of the substrate (17).

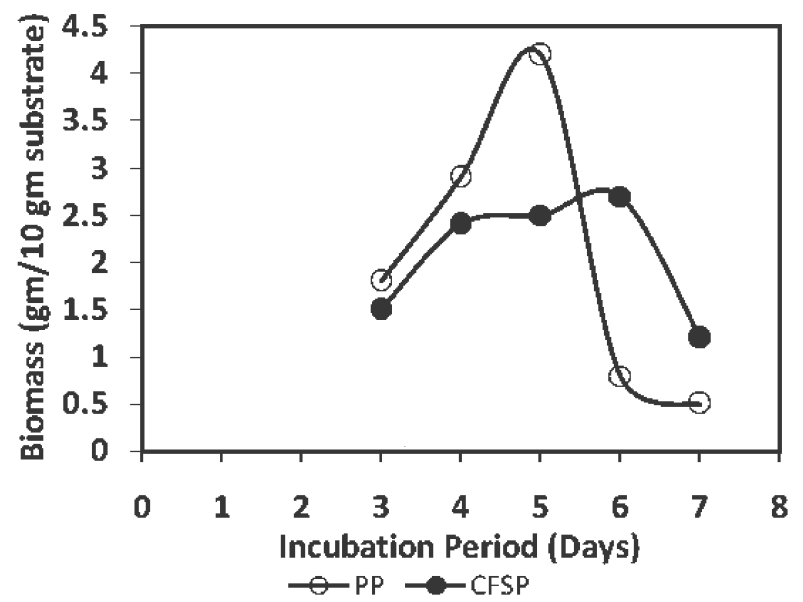

Fig. 3. Effect of time on biomass production

The CMC assay is used to measure the released Endo $\beta$ glucanase during the degradation of cellulose. When PP were used as substrate cellulase activity was at its peak with $33.141 \mathrm{IU} / \mathrm{ml}$ on day 6 which decreased to $11.51 \mathrm{IU} / \mathrm{ml}$ on day 7 . In case of CFSP cellulase activity was found out to be highest with $6.278 \mathrm{IU} / \mathrm{ml}$ on day 6 which also decreased on day 7 (Figure 4). The filter paper assay is a combined assay for endo and exo beta glucanase during the degradation of cellulose. The FPA activity of $32.69 \mathrm{IU} / \mathrm{ml}$ was noticed on day 6 when PP were used as substrate. CFSP gave rise to FPA activity of $18.21 \mathrm{IU} / \mathrm{ml}$ on day 6 . In both cases activity decreased on day 7(Figure 5). The decrease in enzyme activity after day 6 may be attributed to cumulative effect of cellobiose (20). Nutritional and environmental factors such as type of carbon source, period of cultivation, agitation affect enzyme synthesis and production by fungi $(21,22,23)$. Fermentation period is an important parameter for growth as well as for the production of enzymes. Thus optimization of these conditions could lead to the optimal enzyme production and an effective waste management.

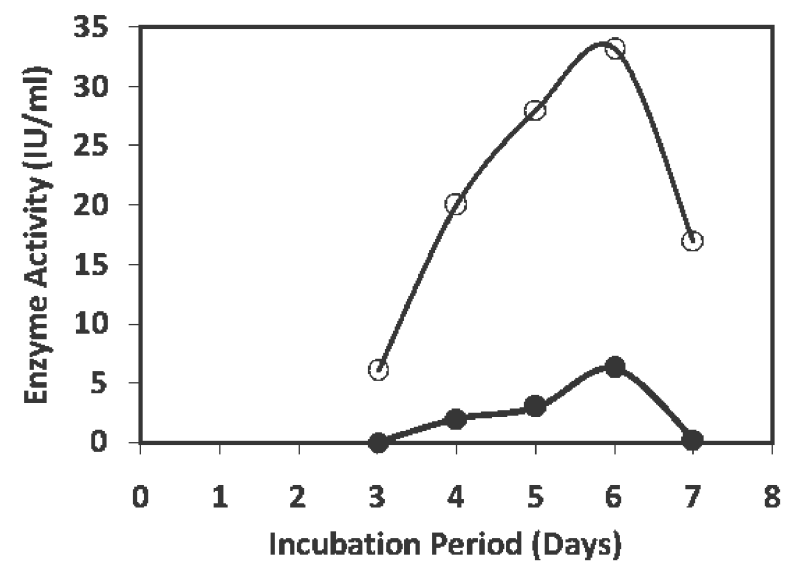

Fig. 4. Effect of time on enzyme activity given by CMC assay

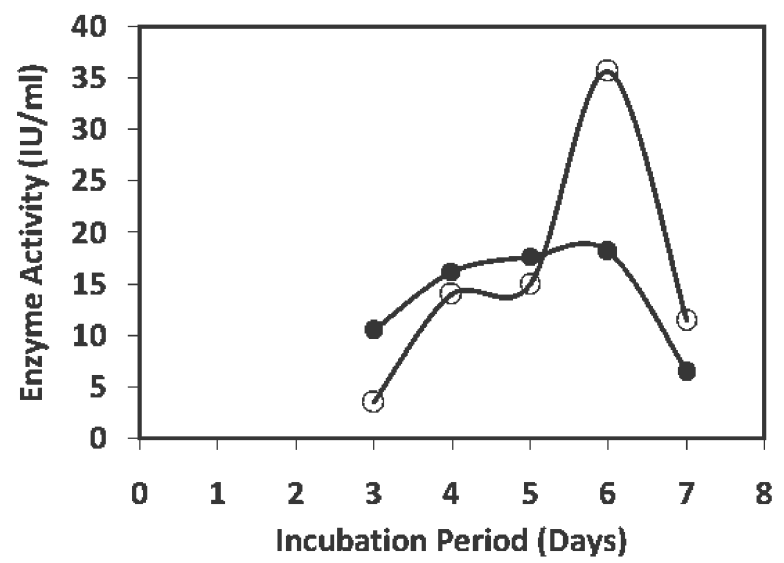

Fig. 5. Effect of time on enzyme activity given by FPA 


\section{CONCLUSIONS}

In this investigation, the waste cauliflower stalk proved to be a good source for production of cellulase by endophytic Aspergillus $s p$. The production of cellulase could be achieved simultaneously with waste management. Further investigations are required to utilise the potential of the endophyte for cellulase production by employing genetic, biochemical and microbial engineering techniques.

\section{ACKNOWLEDGEMENT}

We are thankful to Sathyabama University for their support.

\section{REFERENCES}

[1] V Priti, B T Ramesha, Shweta Singh, G Ravikanth,K N Ganeshaiah, T S Suryanarayanan, How promising are endophytic fungi as alternative sources of plant secondary metabolites?,Current Science, vol 97, No 4, 25 August 2009.

[2] Wang, J.G.Li ,H. Lu,Z. Zheng, Y. Huang and W.Su , 2000, Taxol from Tubercularia sp. Strain TF5, an endophytic fungus of Taxus mairei, FEMS Microbiology Letters, 193,pp249-253.

[3] Tomita F.,2003, Endophytes in Southeast Asia and Japan:their taxonomic diversity and potential applications, Fungal Diversity , 14, pp 187-204.

[4] Carroll,G.C and Petrini,O., 1983, Patterns of substrate utilisation by some endophytes from coniferous foliage, Mycologia, 75:pp 53-63.

[5] Ng'ang'a MP, Kahangi EM, OngusoJM, Losenge T and Mwaura P, December 2011,Analysis of extracellular enzymes production by endophytic fungi isolated from bananas in Kenya, African Journal of Horticultural Science, 5,pp1-8.

[6] Godliving Y.S Mtui, April 2012,Lignocellulolytic enzymes from tropical fungi: Types, substrates and applications, Scientific Reasearch and Essays ,7(15), pp1544-1555.

[7] V Gangadevi and J Muthumary, "Isolation of Colletotrichum gloeosporioides, a novel endophytic taxol producing fungus from the leaves of a medicinal plant, Justicia gendarussa, " Mycologia Balcanica 5 ,2008,pp 1-4.

[8] K Nithya \& J Muthumary ,"Bioactive metabolite produced by Phomopsis sp; an endophytic fungus in Allamanda cathartica ," Linn. Recent Research in Science \& Technology ,3(3),2011,pp44-48.

[9] V Kumaresan \& T S Suryanarayanan. "Endophytic assemblages in young, mature and senescent leaves of Rhizophora apiculata : Evidence for the role of endophytes in mangrove litter degradation," Fungal Diversity, 9,2002,pp 81-91.

[10] T.K. Ghose, "Measurement of cellulase activities," Pure \& Appl. Chem, Vol.59 , No.2, pp 257-268,1987.

[11] M.M.Dreyfuss and I. Chapel, (1994) "Potential of fungi in the discovery of novel, low molecular weight pharmaceuticals," In: The discovery of natural products with therapeutic potential, ed. By V.P. Gullo, Butter-Worth-Heinemann, London, UK. pp 49-80

[12] G.L.Maria,K.R.Sridhar and N.S.Raviraja , "Antimicrobial and enzyme activity of mangrove endophytic fungi of southwest coast of India, " J. Agricultural Technol., 1,2005,pp 67-80.

[13] Wilson,D., Ecology of woody plant endophytes in:Microbial Endophytes(eds. C.W.Bacon \& J. F. White Jr.) Marcel Dekker, NewYork, pp-389-420.

[14] Frohlich,J., Hyde,K.D and Petrini O, 2000, Endophytic fungi associated with palms, Mycoligical Research, 104,pp1202-1212.

[15] Mtui GYS ,2009, Recent Advances in pretreatment of lignocellulosic wastes and production of value added products, African Journal of Biotechnology. 8(8),pp1398-1415

[16] A.Vyas and D. Vyas , "Isolation and screening of cellulases producing fungj from diverse habitats, ," J. Basic Appl. Mycol., 4(I \& II), 138-141.

[17] Moumita Karmakar, Rina Rani Ray , "Saccharification of agro wastes by the Endoglucanase of Rhizopus oryzae, " Annals of Biological research, 2(1),201-208,2011

[18] Mohamed Ashour, Hany M Yehia, Peter Proksch, 2011, Utilisation of Agroindustrial byproducts for production of bioactive natural products from endophytic fungi, Journal of Natural Products,4,pp 108-114.

[19] Asad MJ, Asgher M, Sheikh MA, Sultan Jl,2006, Production of Neurospora Sitophila cellulases in solid state cultures, Jourbal of Chem.Soc.Pak., 28(6)pp 590-595.

[20] S.P.Gautam, P.S.Bundela,A.K.Pandey,Jamaludin Khan,M.K.Awasthi and S.Sarsaiya,2011, "Optimisation for the production of cellulase enzyme from municipal solid waste residue by two novel cellulolytic fungi," Biotechnology Research International, 8 pages

[21] M Sorgatto,N.C.A. Guimaraes,F.F.Zanoelo et al, 2012, Purification and characterisation of an extracellular xylanase produced by the endophytic fungus , Aspergillus terreus, grown in submerged fermentation, African Journal of Biotechnology, 11(32),pp8076-8084.

[22] S.Nataraja,D.M. Chetan and M.Krishnappa , "Effect of temperature on cellulose enzyme activity in crude 
extracts isolated from solid wastes microbes," International Journal of Microbiology Research, Vol 2, 2010, pp44-47.

[23] M.A.Milala, A. Shugaba, A.Gidado, A.C. Ene and J.A. Wafar, "Studies on the use of agricultural wastes for cellulase enzyme production by Aspergillus niger," Research Journal of Agriculture and Biological Sciences 1 (4),2005,325-328.

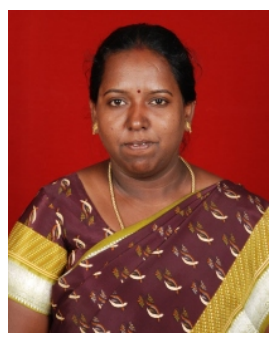

The first author Prabavathy a part time Research Scholar is presently an Assistant Professor in the Department of Biotechnology. Her field of interest are Molecular Biology, Genetics \& Microbiology. 